\title{
POLA SEGREGASI KARAKTER AGRONOMI TANAMAN KEDELAI (Glycine max [L.] Merrill) GENERASI F 2 HASIL PERSILANGAN YELLOW BEAN DAN TAICHUNG
}

\author{
Wastudiawan Pramana Nugroho, Maimun Barmawi \& Nyimas Sa'diyah \\ Jurusan Agroteknologi, Fakultas Pertanian Universitas Lampung \\ J1. Prof. Soemantri Brodjonegoro, No.1 Bandar Lampung 35145 \\ E-mail:wastudiawanpn@gmail.com
}

\begin{abstract}
ABSTRAK
Pola segregasi suatu karakter merupakan salah satu parameter genetik yang perlu diketahui dalam hubungannya dengan proses seleksi. Penelitian ini bertujuan untuk mengetahui bentuk sebaran dan pola segregasi serta jumlah gen yang mengatur karakter agronomi kedelai generasi $\mathrm{F}_{2}$ hasil persilangan Yellow Bean dan Taichung. Penelitian ini dilaksanan di Kebun Percobaan Universitas Lampung Gedung Meneng, Kecamatan Rajabasa Bandar Lampung dan di Laboratorium Benih dan Pemuliaan Tanaman Fakultas Pertanian Universitas Lampung pada bulan November 2011 sampai dengan Februari 2012. Penelitian ini dilakukan dengan rancangan percobaan tanpa ulangan dan data dianalisis dengan menggunakan uji khi-kuadrat untuk kesesuaian distribusi normal dan kesesuaian antara nilai pengamatan dan nilai harapan. Hasil penelitian menunjukkan karakter umur berbunga, tinggi tanaman, jumlah polong per tanaman dan bobot 100 butir berdistribusi normal sehingga karakterkarakter tersebut termasuk dalam karakter kuantitatif yang dikendalikan oleh banyak gen. Untuk karakter umur panen, jumlah cabang produktif, dan bobot biji per tanaman termasuk dalam karakter kualitatif dan jumlah gen yang mengendalikannya yaitu dua gen yang bersifat epistasis dominan-resesif dengan nisbah 13:3.
\end{abstract}

Kata Kunci: Generasi $\mathrm{F}_{2}$, kedelai, dan pola segregasi

\section{PENDAHULUAN}

Produksi kedelai nasional tahun 2010 sebanyak 908,11 ribu ton dan impor kedelai sepanjang tahun 2010 sebanyak 1,7 juta ton atau senilai 840 juta dolar AS, utamanya dari Amerika Serikat, Malaysia, Argentina, Kanada, dan Thailand. Pada tahun 2012 krisis kenaikan harga kedelai yang menjadi bahan baku tahu dan tempe merupakan yang terparah dibandingkan kenaikan harga kedelai pada tahun-tahun sebelumnya. Hal ini disebabkan oleh kenaikan harga kedelai di dunia (Putra, 2012).

Usaha peningkatan produksi kedelai nasional perlu dilakukan sehingga ketergantungan pada kedelai impor dapat dikurangi dan devisa negara dapat dihemat. Peningkatan produksi secara kuantitas maupun kualitas dapat ditempuh melalui penggunaan varietas unggul. Perakitan varietas unggul dapat dilakukan melalui program pemuliaan tanaman. Persilangan merupakan proses penting dalam pemuliaan, karena persilangan berfungsi sebagai sumber untuk menimbulkan keragaman genetik pada keturunannya di samping berpotensi untuk menghasilkan galur homozigot yang menjadi landasan pembentukan varietas baru (Bari dkk., 1974). Pada tanaman menyerbuk sendiri tingkat segregasi yang tertinggi terjadi pada generasi $\mathrm{F}_{2}$ (Welsh, 1991). Menurut (Crowder, 1997), tingkat segregasi dan rekombinan yang luas pada generasi ini tergambarkan melalui sebaran frekuensi genotipenya. Hal tersebut dapat digunakan sebagai penduga pewarisan sifat dan jumlah gen yang terlibat dalam pengendali suatu sifat.

Penelitian tentang pola segregasi ini, dilakukan melalui beberapa pendekatan karakter agronomi pada tanaman generasi $\mathrm{F}_{2}$ kedelai hasil persilangan Yellow Bean da Taichung. Genotipe Taichung memiliki keunggulan yang tahan terhadap SSV (Soybean Stunt Virus) dan bijinya besar tetapi jumlah polong per tanaman sedikit sehingga produksinya rendah. Genotipe Yellow Bean memiliki keunggulan jumlah polong per tanaman banyak tetapi bijinya kecil dan rentan terhadap SSV (Akin dan Barmawi, 2005).

Karakter agronomi merupakan karakter tanaman berdasarkan morfologi dan hasil tanaman yang dibagi ke dalam karakter kualitatif dan karakter kuantitatif. Karakter kualitatif umumnya dicirikan dengan sebaran fenotipenya diskontinu yang dikendalikan oleh gen monogenik ataupun oligogenik yang pengaruh gen secara individu mudah dikenal. Karakter kuantitatif umumnya dicirikan oleh sebaran fenotipenya kontinu atau menunjukkan sebaran normal dan dikendalikan oleh 
banyak gen yang masing-masing gen berpengaruh kecil terhadap ekspresi suatu karakter (Trustinah, 1997).

Karakter jumlah polong per tanaman dan bobot biji per tanaman merupakan karakter kuantitatif. Hasil penelitian Sriwidarti (2011) menunjukkan bahwa pada tanaman kacang panjang, karakter-karakter ini dikendalikan oleh banyak gen yang berdistribusi normal dengan satu puncak. Karakter umur berbunga, umur panen, dan tinggi tanaman dikendalikan oleh banyak gen dan termasuk dalam karakter kuantitatif. Penelitian Limbongan dkk. (2008) menunjukkan bahwa umur berbunga pada tanaman padi sawah dikendalikan oleh banyak gen.

Karena itu, dalam menentukan strategi pemuliaan tanaman kedelai, pengetahuan tentang pola segregasi mempunyai arti yang sangat penting agar program pemuliaan menjadi efektif. Penelitian ini bertujuan untuk mengestimasi bentuk sebaran dan pola segregasi serta jumlah gen yang mengatur karakter agronomi kedelai generasi $\mathrm{F}_{2}$ hasil persilangan Yellow Bean dan Taichung.

\section{METODE PENELITIAN}

Penelitian dilaksanakan di kebun percobaan Universitas Lampung dari bulan Oktober 2012 sampai dengan Februari 2012. Benih yang digunakan adalah benih $\mathrm{F}_{2}$ Yellow Bean $\mathrm{x}$ Taichung hasil pemuliaan Dr. Ir. Maimun Barmawi, M.S. Penelitian ini dilakukan dengan rancangan percobaan tanpa ulangan karena benih yang digunakan adalah benih $\mathrm{F}_{2}$ yang masih mengalami segregasi (Baihaki, 2000).

Kedelai ditanam sebayak 160 benih pada petak percobaan berukuran $5 \times 5 \mathrm{~m}$ dengan jarak tanam $20 \mathrm{x}$ $60 \mathrm{~cm}$, tanaman umur tujuh hari setelah tanam dipupuk dengan Urea dosis 50 kg/ha, SP-36 dan KCL 100 kg/ ha. Pemberian pupuk dilakukan dengan cara membuat lubang $\pm 15 \mathrm{~cm}$ dari lubang tanam dan pemberian urea dipisahkan dari lubang SP-36 dan KCL. Untuk mencegah serangan hama dan penyakit diaplikasikannya insektisida berbahan aktif Deltametrin dan fungisida berbahan aktif Mankozep 80\% setiap seminggu. Peubah yang diamati adalah umur berbunga, umur panen, tinggi tanaman, jumlah cabang produktif, jumlah polong per tanaman, bobot biji per tanaman dan bobot 100 butir.

Analisis data yang dilakukan meliputi uji kesesuaian distribusi normal dan uji khi-kuadrat untuk menguji kesesuaian antara nilai pengamatan dan nilai harapan. Pengujian kesesuaian distribusi normal digunakan uji khi-kuadrat (Gomez dan Gomez, 1984). Adapun tahapan perhitungannya sebagai berikut :

1. Banyaknya data pengamatan $(n)$ dinyatakan ke dalam tabel frekuensi.
2. Dari tabel frekuensi yang telah dibuat, dihitung rataan $(\bar{X})$, ragam $\left(s^{2}\right)$, dan simpangan baku (s) sebagai berikut:

Rata-rata : $\bar{X}=\frac{\sum_{i=1}^{p}(f i)(X i)}{\sum_{i=1}^{p}(f i)}$

Ragam $: s^{2}=\frac{1}{\sum_{i=1}^{p} f i-1}\left\{\sum_{i=1}^{p}(f i)\left(X i^{2}\right)-\frac{\left[\sum_{i=1}^{p}(f 1)(X i)^{2}\right]}{\sum_{i=1}^{p} f i}\right\}$

Simpangan baku $: \mathrm{s}=\sqrt{s^{2}}$

3. Pada setiap kelas, dihitung nilai $Z$ baku, satu untuk batas terendah $\left(Z_{l}\right)$ dan lainnya batas tertinggi $\left(Z_{h}\right)$

$$
Z i=\frac{L i-\bar{X}}{s} \quad Z h=\frac{L h-\bar{X}}{s}
$$

4. Peluang setiap selang kelas ditentukan berdasarkan hipotesis sebaran peluang sebagai berikut:

$\mathrm{P}=\mathrm{P}\left(\mathrm{Z}_{\mathrm{i}}<\mathrm{X}<\mathrm{Z}_{\mathrm{h}}\right)$

5. Frekuensi harapan untuk kelas ke-i (Fi) dengan rumus sebagai berikut:

$\mathrm{F}_{\mathrm{i}}=(\mathrm{n})\left(\mathrm{P}_{\mathrm{i}}\right)$

6. Rumus $x^{2}$-hitung sebagai berikut (Gomez dan Gomez, 1984):

$$
X^{2}=\sum_{i=1}^{p} \frac{(f i-F i)^{2}}{F i}
$$

Keterangan :

$\mathrm{F}_{\mathrm{i}}$ : Nilai kelas ke- $i$

$\mathrm{f}_{\mathrm{i}}$ : Frekuensi pengamatan

Hipotesis pertama $\left(\mathrm{H}_{0}\right)$ menduga bahwa uji kesesuaian distribusi normal karakter agronomi kedelai generasi $\mathrm{F}_{2}$ hasil persilangan Yellow Bean $\mathrm{x}$ Taichung berdistribusi normal; dengan demikian $\mathrm{H}_{0}$ diterima bila $X_{\text {hitung }}<X^{2}$ tabel. Sebaliknya, $\mathrm{H}_{0}$ ditolak jika $X_{\text {hitung }}{ }>X^{2}$ tabel.

Sebaran frekuensi untuk karakter yang berdistribusi normal dilakukan dengan uji kemenjuluran untuk mengetahui kurva yang bersangkutan setangkup. Bentuk sebaran karakter dikatakan normal apabila nilai SK (Simpangan Kemenjuluran) terletak antara -3 dan +3 (Walpole, 1997). Rumus hitung SK sebagai berikut:

$$
S K=\frac{3(\bar{x}-\tilde{x})}{s}
$$


Keterangan: $\mathrm{SK}=$ simpangan kemenjuluran; $\bar{x}=$ nilai tengah; $\tilde{x}=$ median; $s=$ simpangan baku.

Untuk mengestimasi gen pengendali yang bersifat sederhana, maka populasi $\mathrm{F}_{2}$ akan dicocokkan terhadap beberapa nisbah, tergantung dari bentuk grafik yang diperoleh (Snyder dan David, 1957 dikutip oleh Barmawi, 1998). Jika grafik penyebaran populasi $F_{2}$ menunjukkan 1. Dua puncak, kemungkinan nisbah yang terjadi adalah 3:1 (satu gen dominan penuh), 9:7 (dua gen epistastis resesif duplikat), 13:3 (dua gen epistasis dominan resesif), atau 15:1 (dua gen dominan duplikat).

2. Tiga puncak, kemungkinan nisbah yang terjadi adalah 1:2:1 (satu gen dominan tidak sempurna), 9:3:4 (dua gen epistasis resesif), 9:6:1 (dua gen dengan efek kumulatif) dan 12:3:1 (dua gen epistasis dominan).

3. Lebih dari tiga puncak, kemungkinan nisbah yang terjadi adalah 9:3:3:1 (dua gen dominan penuh) atau 6:3:3:4 (satu pasang gen dominan sempurna dan satu pasang gen dominan sebagian).

4. Satu puncak dan distribusinya menyebar normal, karena itu, karakter yang ditelaah dikendalikan oleh banyak gen.

Dengan demikian $\mathrm{H}_{0}$ diterima bila $X_{\text {hitung }}^{2}<X^{2}$ tabel. Sebaliknya, $\mathrm{H}_{0}$ ditolak jika $X^{2}{ }_{\text {hitung }}>X^{2}{ }_{\text {tabel. }}$ Pengujian kesesuaian antara nilai pengamatan dan nilai harapan digunakan uji khi-kuadrat yang tergantung dari banyaknya kelas (Gomez dan Gomez, 1984)..

a. Dua kelas

$\chi^{2}=\sum_{j=1}^{c} \frac{\left(10_{j}-E_{j} \mid-0,5\right)^{2}}{E_{j}}$

b. Lebih dari dua kelas

$\chi^{2}=\sum_{j=1}^{c} \frac{\left(O_{j}-E_{j}\right)^{2}}{E_{j}}$
Keterangan:

$\mathrm{O}, \quad=$ nilai pengamatan dalam kelas ke- $\mathrm{j}$

$\mathrm{E}_{\mathrm{j}} \quad=$ nilai harapan dalam kelas ke- $\mathrm{j}$

$\mathrm{j}=1,2,3, \ldots \mathrm{c}$

\section{HASIL DAN PEMBAHASAN}

Hasil uji normalitas karakter agronomi tanaman kedelai populasi $\mathrm{F}_{2}$ hasil persilangan Yellow Bean dan Thaicung menunjukkan bahwa karakter-karakter yang mengikuti sebaran normal yaitu tinggi tanaman, umur berbunga, jumlah polong per tanaman dan bobot 100 butir dengan didukung oleh hasl uji kemenjuluran (Tabel 1, 2 dan Gambar 1), sedangkan karakter-karakter yang tidak mengikuti sebaran normal yaitu umur panen, jumlah cabang produktif, dan bobot biji per tanaman (Tabel 1 dan Gambar 1).

Karakter tinggi tanaman, umur berbunga, jumlah polong per tanaman dan bobot 100 butir termasuk dalam karakter kuantitatif yang dikendalikan oleh banyak gen yang masing-masing gen berpengaruh kecil terhadap ekspresi suatu karakter (Trustinah, 1997). Hasil penelititan ini sesuai dengan penelitian Limbongan dkk (2008) yang menunjukkan bahwa karakter umur berbungan dan tinggi tanaman pada tanaman padi sawah dikendalikan oleh poligen. Begitu juga dengan karakter jumlah polong per tanaman dan bobot 100 butir, sesuai dengan penelitian Sriwidarti (2011) yang menunjukkan bahwa karakter jumlah polong per tanaman dan bobot 100 butir pada tanaman kacang panjang merupakan karakter kuantitatif yang mengikuti sebaran normal dan dikendalikan oleh banyak gen. Menurut Baihaki (2000), karakter kuantitatif merupakan karakter yang dikendalikan oleh banyak gen yang masing-masing gen berkontribusi terhadap penampilan karakter yang dianalisis, dan peran dari masing-masing gen tidak besar. Hal ini menyebabkan pola segregasi untuk karakter umur berbunga, tinggi tanaman, jumlah polong per tanaman

Tabel 1. Uji khi-kuadrat untuk kesesuaian distribusi normal karakter agronomi

\begin{tabular}{llcll}
\hline No & \multirow{2}{*}{ Karakter yang diamati } & $\mathrm{X}^{2}{ }_{\text {hitung }}=?(\mathrm{f} i-\mathrm{F} i)^{2}$ & $\mathrm{X}^{2}{ }_{0,05}$ & \multicolumn{1}{c}{ Keputusan } \\
\hline 1 & Umur berbunga & $13,06^{\text {th }}$ & & Berdistribusi normal \\
2 & Umur Panen & $64,45^{*}$ & & Tidak berdistribusi normal \\
3 & Tinggi Tanaman & $10,05^{\text {th }}$ & & Berdistribusi normal \\
4 & Jumlah cabang produktif & $34,54^{*}$ & \multirow{2}{*}{14,07} & Tidak berdistribusi normal \\
5 & Jumlah polong per tanaman & $13,92^{\text {th }}$ & & Berdistribusi normal \\
6 & Bobot 100 butir & $4,25^{\text {tn }}$ & & Berdistribusi normal \\
7 & Bobot biji per tanaman & $22,95^{*}$ & & Tidak berdistribusi normal \\
\hline
\end{tabular}

Keterangan : tn $=$ Tidak nyata pada taraf $\alpha_{0,05} *$ Nyata pada $\alpha_{0,05}$. 


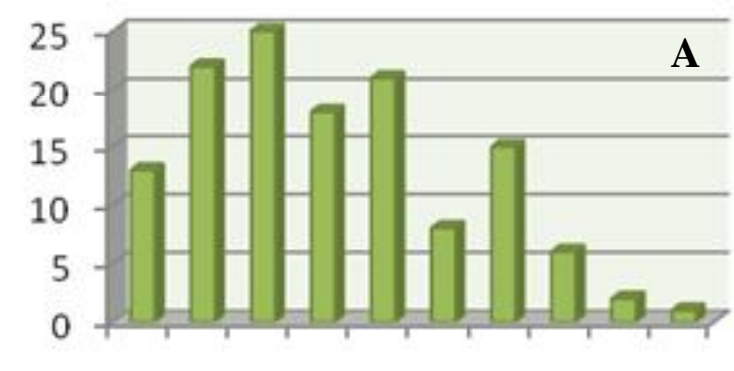

$\begin{array}{llllllllll}1 & 2 & 3 & 4 & 5 & 6 & 7 & 8 & 9 & 10\end{array}$

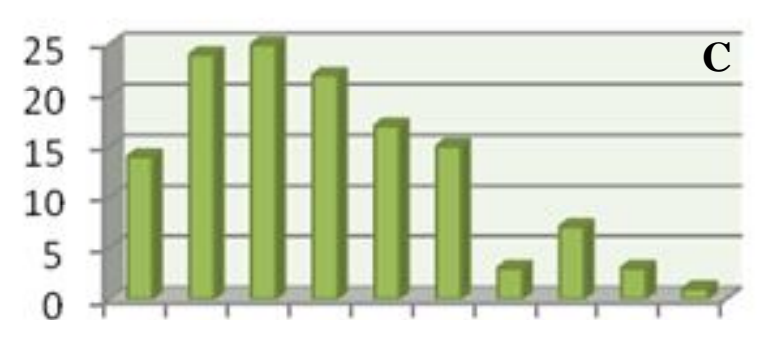

$\begin{array}{llllllllll}1 & 2 & 3 & 4 & 5 & 6 & 7 & 8 & 9 & 10\end{array}$

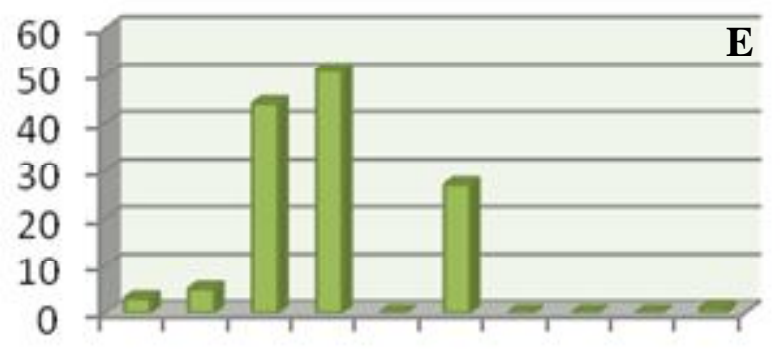

$\begin{array}{llllllllll}1 & 2 & 3 & 4 & 5 & 6 & 7 & 8 & 9 & 10\end{array}$

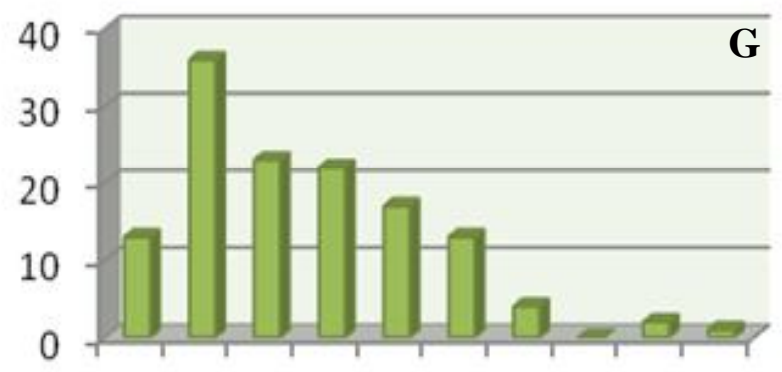

$\begin{array}{llllllllll}1 & 2 & 3 & 4 & 5 & 6 & 7 & 8 & 9 & 10\end{array}$

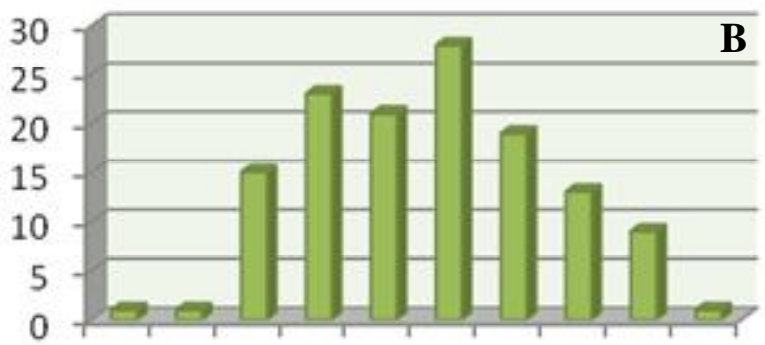

$\begin{array}{llllllllll}1 & 2 & 3 & 4 & 5 & 6 & 7 & 8 & 9 & 10\end{array}$

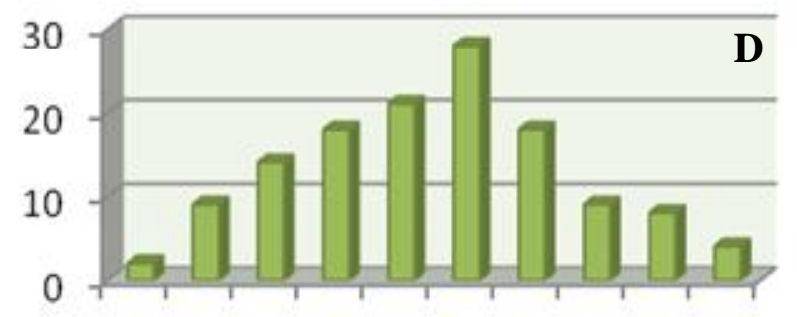

$\begin{array}{llllllllll}1 & 2 & 3 & 4 & 5 & 6 & 7 & 8 & 9 & 10\end{array}$

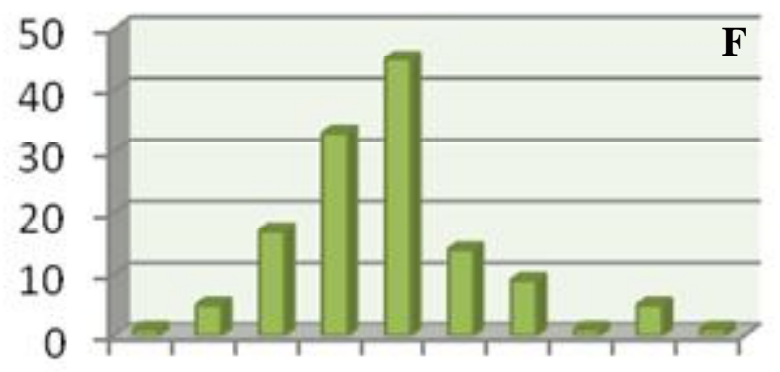

$\begin{array}{llllllllll}1 & 2 & 3 & 4 & 5 & 6 & 7 & 8 & 9 & 10\end{array}$

Gambar 1. Grafik kesesuaian distribusi normal karakter (A) umur berbunga, (B) tinggi tanaman, (C) jumlah polong per tanaman dan (D) bobot 100 butir, (E) umur panen, (F) jumlah cabang produksi, dan (G) bobot biji per tanaman kedelai populasi $\mathrm{F}_{2}$ hasil persilangan Yellow Bean dan Taichung.

Tabel 2. Hasil uji kemenjuluran pada karakter yang berdistribusi normal

\begin{tabular}{lll}
\hline Karakter yang berdistribusi normal & Nilai SK & \multicolumn{1}{c}{ Keterangan } \\
\hline Umur Berbunga & 0,49 & Berdisttribusi normal; sedikit menjulur ke kanan \\
Tinggi Tanaman & $-0,0075$ & Berdisttribusi normal; sedikit menjulur ke kiri \\
Jumlah Polong per Tanaman & 0,52 & Berdisttribusi normal; sedikit menjulur ke kanan \\
Bobot 100 butir & $-0,058$ & Berdisttribusi normal; sedikit menjulur ke kiri \\
\hline
\end{tabular}


dan bobot 100 butir sukar diidentifikasi dan pewarisannya tidak sesederhana seperti pada genetika Mendel.

Pada karakter umur panen, jumlah cabang produktif, dan bobot biji per tanaman, $\chi^{2}{ }_{\mathrm{h}}>\chi^{2}{ }_{0,05}$ sehingga dapat diambil keputusan bahwa karakter-karakter tersebut tidak mengikuti sebaran normal (Tabel 1). Hal ini menunjukkan bahwa karakter umur panen, jumlah cabang produktif dan bobot biji per tanaman merupakan karakter kualitatif yang dikendalikan oleh sedikit gen.
Oleh karena itu, perlu dilakukan uji signifikansi untuk berbagai nisbah teoretis populasi $\mathrm{F}_{2}$ khusus untuk karakter umur panen, jumlah cabang produktif dan bobot biji per tanaman.

Karakter umur panen, jumlah cabang produktif, dan bobot biji per tanaman mengikuti segregasi 13:3 dengan peluang berturut-turut 50-75\%, 5-10\%, dan 75$90 \%$ (Tabel 3, 4, 5). Pola segregasi populasi $\mathrm{F}_{2}$ untuk karakter-karakter tersebut mengikuti nisbah 13:3 yang

Tabel 3. Uji khi-kuadrat nisbah pola segregasi karakter umur panen, generasi $\mathrm{F}_{2}$ Yellow Bean $\mathrm{x}$ Taichung

\begin{tabular}{|c|c|c|c|c|c|}
\hline Pola Segregasi & Pengamatan $(\mathrm{O})$ & Harapan (E) & $\chi_{\mathrm{h}}^{2}$ & $\chi_{0,05}^{2}$ & Peluang \\
\hline \multicolumn{6}{|l|}{ Dua Kelas } \\
\hline $3: 1$ & 103:28 & $98,25: 32,75$ & $0,73^{\text {tn }}$ & \multirow{4}{*}{3,94} & $0,30-0,50$ \\
\hline $9: 7$ & 103:28 & $73,68: 57,32$ & $25,75 * *$ & & $<<0,005$ \\
\hline $13: 3$ & $103: 28$ & $106,5: 24,5$ & $0,43^{\text {tn }}$ & & $0,50-0,75$ \\
\hline $15: 1$ & 103:28 & $122,8: 8,2$ & $48,5^{* *}$ & & $<<0,005$ \\
\hline \multicolumn{6}{|l|}{ Tiga Kelas } \\
\hline $1: 2: 1$ & $103: 26: 2$ & $32,75: 65,5: 32,75$ & $203,38 * *$ & \multirow{4}{*}{5,99} & $<<0,005$ \\
\hline $9: 3: 4$ & $103: 26: 2$ & $73,7: 24,5: 32,75$ & $40,6^{* *}$ & & $<<0,005$ \\
\hline $9: 6: 1$ & $103: 26: 2$ & $73,7: 49,125: 8,18$ & $27,22 * *$ & & $<<0,005$ \\
\hline $12: 3: 1$ & $103: 26: 2$ & $98,25: 24,6: 8,18$ & $4,98^{\mathrm{tn}}$ & & $0,05-0,25$ \\
\hline \multicolumn{6}{|l|}{ Empat Kelas } \\
\hline $9: 3: 3: 1$ & $52: 51: 26: 2$ & $73,7: 24,6: 24,6: 8,1$ & $39,6^{* *}$ & 7,81 & $<<0,005$ \\
\hline \multicolumn{6}{|l|}{ Lima Kelas } \\
\hline $1: 4: 6: 4: 1$ & 39:64:27:0:1 & $8,2: 32,8: 49: 32,8: 8,2$ & $194,8 * *$ & 9,49 & $<<0,005$ \\
\hline
\end{tabular}

Keterangan : tn (Tidak nyata) dan * (Nyata pada taraf $\alpha_{0,05}$ )

Tabel 4. Uji khi-kuadrat nisbah pola segregasi karakter jumlah cabang produktif, generasi $\mathrm{F}_{2}$ Yellow Bean $\mathrm{x}$ Taichung

\begin{tabular}{|c|c|c|c|c|c|}
\hline Pola Segregasi & Pengamatan (O) & Harapan (E) & $\chi_{h}^{2}$ & $\chi_{0,05}^{2}$ & Peluang \\
\hline \multicolumn{6}{|l|}{ Dua Kelas } \\
\hline $3: 1$ & $115: 15$ & $98,25: 32,75$ & $10,7 * *$ & \multirow{4}{*}{3,94} & $<<0,005$ \\
\hline $9: 7$ & $115: 15$ & $73,68: 57,32$ & $51,67 * *$ & & $<<0,005$ \\
\hline $13: 3$ & $115: 15$ & $106,5: 24,5$ & $3,25^{\mathrm{tn}}$ & & $0,05-0,10$ \\
\hline $15: 1$ & $115: 15$ & $122,8: 8,2$ & $6,96^{\mathrm{tn}}$ & & $0,025-0,05$ \\
\hline \multicolumn{6}{|l|}{ Tiga Kelas } \\
\hline $1: 2: 1$ & $56: 69: 6$ & $32,75: 65,5: 32,75$ & $38,54 * *$ & \multirow{4}{*}{5,99} & $<<0,005$ \\
\hline $9: 3: 4$ & $56: 69: 6$ & $73,7: 24,5: 32,75$ & $106,49 * *$ & & $<<0,005$ \\
\hline $9: 6: 1$ & $56: 69: 6$ & $73,7: 49,125: 8,18$ & $12,87 * *$ & & $<<0,005$ \\
\hline $12: 3: 1$ & 56:69:6 & $98,25: 24,6: 8,18$ & $99,15^{* *}$ & & $<<0,005$ \\
\hline \multicolumn{6}{|l|}{ Empat Kelas } \\
\hline 9:3:3:1 & $23: 92: 15: 1$ & $73,7: 24,6: 24,6: 8,1$ & $230,05^{* *}$ & 7,81 & $<<0,005$ \\
\hline \multicolumn{6}{|l|}{ Lima Kelas } \\
\hline $1: 4: 6: 4: 1$ & $6: 50: 59: 10: 6$ & $8,2: 32,8: 49: 32,8: 8,2$ & $28,04 * *$ & 9,49 & $<<0,005$ \\
\hline
\end{tabular}

Keterangan : tn (Tidak nyata) dan * (Nyata pada taraf $\alpha_{0,05}$ ) 
Tabel 5. Uji khi-kuadrat nisbah pola segregasi karakter jumlah polong per tanaman, generasi $\mathrm{F}_{2}$ Yellow Bean $\mathrm{x}$ Taichung

\begin{tabular}{|c|c|c|c|c|c|}
\hline Pola Segregasi & Pengamatan (O) & Harapan (E) & $\overline{\chi_{h}^{2}}$ & $\chi_{0,05}^{2}$ & Peluang \\
\hline \multicolumn{6}{|l|}{ Dua Kelas } \\
\hline $3: 1$ & $108: 23$ & $98,25: 32,75$ & $3,48^{\mathrm{tn}}$ & \multirow{4}{*}{3,94} & $0,05-0,10$ \\
\hline $9: 7$ & $108: 23$ & $73,68: 57,32$ & $35,46^{* *}$ & & $<<0,005$ \\
\hline $13: 3$ & $108: 23$ & $106,5: 24,5$ & $0,056^{\mathrm{tn}}$ & & $0,75-0,90$ \\
\hline $15: 1$ & 108:23 & $122,8: 8,2$ & $26,68 * *$ & & $<<0,005$ \\
\hline \multicolumn{6}{|l|}{ Tiga Kelas } \\
\hline $1: 2: 1$ & $74: 51: 6$ & $32,75: 65,5: 32,75$ & $77,02 * *$ & \multirow{4}{*}{5,99} & $<<0,005$ \\
\hline $9: 3: 4$ & 74:51:6 & $73,7: 24,5: 32,75$ & $50,3 * *$ & & $<<0,005$ \\
\hline $9: 6: 1$ & 74:51:6 & $73,7: 49,125: 8,18$ & $0,65^{\mathrm{tn}}$ & & $0,50-0,75$ \\
\hline $12: 3: 1$ & 74:51:6 & $98,25: 24,6: 8,18$ & $35,02 * *$ & & $<<0,005$ \\
\hline \multicolumn{6}{|l|}{ Empat Kelas } \\
\hline $9: 3: 3: 1$ & $62: 47: 19: 3$ & $73,7: 24,6: 24,6: 8,1$ & $26,89 * *$ & 7,81 & $<<0,005$ \\
\hline \multicolumn{6}{|l|}{ Lima Kelas } \\
\hline $1: 4: 6: 4: 1$ & 44:42:35:7:3 & $8,2: 32,8: 49: 32,8: 8,2$ & $186,85^{* *}$ & 9,49 & $<<0,005$ \\
\hline
\end{tabular}

Keterangan : tn (Tidak nyata) dan * (Nyata pada taraf $\alpha_{0,05}$ )

bersifat epistasis dominan resesif. Hal ini berarti bahwa karakter-karakter tersebut dikendalikan oleh gen yang bereaksi epistasis dominan-resesif artinya gen dominan pada satu lokus dan gen resesif pada lokus lain mempengaruhi penampakan fenotipe yang sama (Stansfield dan Susan, 2006).

Berdasarkan hasil penelitian ini, maka seleksi untuk karakter umur berbunga, tinggi tanaman, jumlah polong per tanaman dan bobot 100 butir kedelai populasi $\mathrm{F}_{2}$ tidak dapat dilakukan pada generasi awal. Hal ini disebabkan karena karakter-karakter tersebut dikendalikan oleh banyak gen yang berkontribusi secara aditif dan peran dari masing-masing gen kecil serta peran lingkungan berpengaruh besar terhadap penampilan karakter-karakter tersebut. Begitu pula pada karakter umur panen, jumlah cabang produktif dan bobot biji per tanaman juga tidak dapat dilakukan pada generasi awal. Hal ini disebabkan karena pada karakter umur panen, jumlah cabang produktif dan bobot biji per tanaman tidak diwariskan secara langsung dari tetua ke keturunannya yang ditunjukkan adanya efek epistasis di dalam segregasi karakter-karakter tersebut. Oleh karena itu, diharapkan pada generasi-generasi selanjutnya seleksi untuk semua karakter agronomi populasi $\mathrm{F}_{2}$ hasil persilangan Yellow Bean dan Taichung dapat dilakukan dengam efektif.

\section{KESIMPULAN}

Adapun kesimpulan dari penelitian ini adalah bentuk sebaran karakter agronomi tanaman kedelai generasi $\mathrm{F}_{2}$ hasil persilangan Yellow Bean dan Taichung yang meliputi tinggi tanaman, umur berbunga, jumlah polong per tanaman, dan bobot 100 butir berdistribusi normal sedangkan umur panen, jumlah cabang produktif dan bobot biji per tanaman tidak berdistribusi normal. Pola segregasi karakter agronomi tanaman kedelai generasi $\mathrm{F}_{2}$ hasil persilangan Yellow Bean dan Taichung yang meliputi tinggi tanaman, umur berbunga, jumlah polong per tanaman dan bobot 100 butir tidak mengikuti nisbah Mendel atau modifikasinya dan dikendalikan oleh banyak gen. Untuk karakter umur panen, jumlah cabang produktif, dan bobot biji per tanaman mengikuti nisbah 13:3 yang dikendalikan oleh dua gen yang bekerja secara epistasis dominan resesif.

\section{DAFTAR PUSTAKA}

Akin, H.M., M. Barmawi. 2005. Ketahanan Beberapa Varietas Kedelai terhadap SSV (Soybean Stunt Virus). Agrotropika X (1): 15-19. 
Allard, R.W. 1995. Principles of Plant Breeding. John Wiley and Son. Inc. New York-London. 485hlm.

Baihaki, A. 2000. Teknik Rancangan dan Analisis Penelitian Pemuliaan. Fakultas Pertanian Universitas Padjadjaran. Bandung. $120 \mathrm{hlm}$.

Bari, A., S. Musa, E. Sjamsudin. 1974. Pengantar Pemuliaan Tanaman. Bagian Pemuliaan Tanaman Departemen Agronomi. Fakultas Pertanian. IPB. Bogor. $124 \mathrm{hlm}$.

Barmawi, M. 1998. Hubungan antara Ketahanan Tanaman Kedelai terhadap Lalat Kacang dengan Aktifitas Peroksidase dan Penentuan Pola Pewarisannya. Disertasi. Fakultas Pertanian Universitas Padjadjaran. Bandung. 118 hlm.

Crowder, L.V. 1997. Genetika Tumbuhan (Diterjemahkan oleh Lilik Kurdiati dan Sutarso) Cetakan III. Gajah Mada University Press. Yogyakarta. $499 \mathrm{hlm}$.

Gomez, K.A., dan A.A. Gomez. 1984. Statistical procedures for Agriculture Research. An IRRI Book. John Wiley \& Sons. Six ${ }^{\text {th }}$ Edition. New York. $688 \mathrm{hlm}$.
Limbongan, Yusuf L., Hajrial Aswidinnoor., Bambang S. Purwoko., Trikoesoemaningtyas. 2008. Pewarisan Sifat Toleran Padi Sawah (Oryza sativa L.) terhadap Cekaman Suhu Rendah. Bul. Agro. 36 (2) 111-117.

Putra, Yudha Manggala P. 2012. Krisis Harga Kedelai 2012 Terparah. Diakses melalui www.Republika.co.id/berita/nasional/umum/12/ 07/25/m7rb4q-kopti-krisis-harga-kedelai-2012terparah. [14 September 2012].

Sriwidarti. 2011. Pola Pewarisan Karakter Kualitatif dan Kuantitatif Kacang Panjang (Vigna sinensis var. Sesquipedalis L.) Keturunan Testa Coklat $x$ Hitam. Tesis. Universitas Lampung. Bandar Lampung. 1-25 hlm.

Stansfiled W dan Susan Elrod. 2006. Genetika. Edisi keempat. Erlangga. Jakarta. $328 \mathrm{hlm}$

Trustinah. 1997. Pewarisan Beberapa Sifat Kualitatif dan Kuantitatif pada Kacang Tunggak (Vigna unguiculata (L) Walp). Penelitian Pertanian Tanaman Pangan 15(2): 48-54.

Welsh, J.R. 1991. Dasar-dasar Genetika dan Pemuliaan Tanaman. Diterjemahkan oleh Johanes P. Mogea dari Fundamental of Plant Genetics and Breeding. Penerbit Erlangga. Jakarta. 215 hlm. 